\title{
Influence of Tithonia Diversifolia on Maize (Zea mays L.) Yield, Fertility and Infiltration Status of Two Clay Varied Soils
}

\author{
Dayo-Olagbende $\mathrm{G} \mathrm{O}^{1^{*}}$, Akingbola $\mathrm{O} \mathrm{O}^{1}$, Afolabi G S ${ }^{2}$, Ewulo B S ${ }^{1}$ \\ ${ }^{1}$ Department of Crop, Soil and Pest Management, Federal University of Technology, Akure (FUTA), \\ Ondo State, Nigeria. \\ ${ }^{2}$ Department of Agronomy, Federal University of Technology, Minna (FUTMinna), Niger State, Nigeria \\ * Corresponding author email: phemmieisrafel@gmail.com
}

Received: 05 July 2019 / Revised: 17 September 2019 / Accepted: 31 October 2019 / Published: 03 November 2019

\begin{abstract}
Towards a more sustainable soil management through recycling of readily available weeds in Akure, Nigeria, different rates of Tithonia diversifolia (tithonia) were compared on a field trial to evaluate its effect on soil properties. The experiment was sited at two locations in South gate of the Federal University of Technology, Akure. Prior to the field establishment, a composite soil sample was collected and analyzed for physico-chemical properties. The sites were cleared and tilled. The experiment was laid out in a Randomized Complete Block Design (RCBD) with three replicates. The treatments consisted of three levels of tithonia application which are 0,3 and $6 \mathrm{t} \mathrm{ha}^{-1}$. Each experimental unit size was $2 \mathrm{~m} \times 2 \mathrm{~m}$ with $1 \mathrm{~m}$ alleyway. Maize (Zea mays L. var.TZB-SR) seeds were sown at a spacing of 75 $\mathrm{cm}$ by $25 \mathrm{~cm}$ and 10 were randomly sampled per plot for growth and yield parameters. Data were collected on maize yield and soil physical and chemical properties after harvest to ascertain sustainability of the mulch material after cropping. Application of tithonia mulch improved growth, and yield indices of maize as well as soil physical and chemical properties. The contents of soil total $\mathrm{N}$, exchangeable cations, , CEC, Organic matter content, total porosity, moisture content and infiltration rate were found to significantly $(\mathrm{p}>0.05)$ increase in treatments with tithonia mulch. The best result was from the application rate 6 tha $^{-1}$ because it improved and left the soil conserved after harvesting maize. Similar trends were observed at the two sites despite variation in inherent soil properties.
\end{abstract}

Keywords: Maize, mulch, organic matter, soil, infiltration, Tithonia diversifolia,Tithonia

\section{Introduction}

Soil is an overlooked, abused and misused natural resource [1] which is a vital input in Nigeria where agriculture is fundamental to livelihood development [2]. Tropical soils of the southwestern Nigeria are plagued with humaninduced soil degradation because of the expansion of agriculture into marginal areas, deforestation [3], the shortening or elimination of fallows, inappropriate farming practices [4] in other to meet human demands. Human population has tremendously increased over the years while agriculture has not been able to match up with this increase [5]. This places a high demand on soils like tropical soils which have a common problem; degradation [1; 6] Increasing crop productivity from these soils has been of paramount importance [7] which has awakened soil researchers on providing information on how to increase soil productivity to meet up with human demands while conserving the soil.

Although, chemical fertilizers application had been entertained [8] and found to increase soil productivity however, high cost of chemical fertilizers and subsequent damage to the soil has in time shifted focus of researchers to several forms of organic amendment which are readily available [9]. These organic amendments correct the limitations of chemical fertilizers on soil biophysical properties which include, low structural stability, soil compaction, erosion, low buffering capacity, rapid acidification when cropped continuously with nitrogen fertilizers [10;11]. 
Influence of Tithonia Diversifolia on Maize (Zea mays L.) Yield, Fertility and Infiltration Status of Two Clay Varied Soils

Addition of green manures to soil has been found to play a vital role in adequate maintenance of soil organic matter content while at the same time ensuring nutrient availability [12].

Green manure (plants) is often packed aside as waste when clearing the land for cultivation [13]. However, the leaves can be added to soil in form of mulch which is one of the simplest and most beneficial soil conservation practices that can be used in crop cultivation [14].

Mulch is the protective layer of a material spread on the soil. Mulch from organic matter will be incorporated naturally into the soil [15] by the activity of worms and other organisms. Out of the very many plant species used as sources of green manures, Tithonia diversifolia has been said to be particularly promising [16]. It belongs to the family Asteraceae and is commonly referred to as the Mexican sunflower. It is mostly found along roads and farm edges of the tropics in Africa [17]. Research interest in recent times has been focused on Tithonia diversifolia, due to the relatively high nutrient concentration with a focus on food security, soil sustainability and organic matter recycling. Tithonia diversifolia has great potential to increase food production such as maize.

Table 1: Average Nutrient Content of Tithonia diversifolia Leaves on Dry Weight Basis [17]

\begin{tabular}{|l|l|l|l|}
\hline Nutrients & $\mathrm{N}$ & $\mathrm{P}$ & $\mathrm{K}$ \\
\hline Values $(\%)$ & 3.5 & 0.37 & 4.1 \\
\hline
\end{tabular}

Maize is one of most cultivated cereal crops globally [3]. Successful production of maize depends on the correct application of production inputs which would vary as a result of soil properties especially texture, adapted cultivars, plant population density, soil condition, fertilizer application and weed, insect and disease control that are sustainable for agricultural production [18].

\section{Research Methodology}

\subsection{Sites of Experiment}

Concurrent field trials were carried out on two locations at south gate of Federal University of Technology, Akure, South-western Nigeria (Latitude $7^{0} .30^{1}$ and Longitude $5^{0} .15^{1}$ ). The area is in the tropic region and experiences a wet and dry season. Average annual rainfall is about $1524 \mathrm{~mm}$. The annual total radiation hour is about 2000 hours while mean relative humidity is 80 percent. The vegetation of the area is forest with a mixture of different grasses, creepers and bush re-growth.

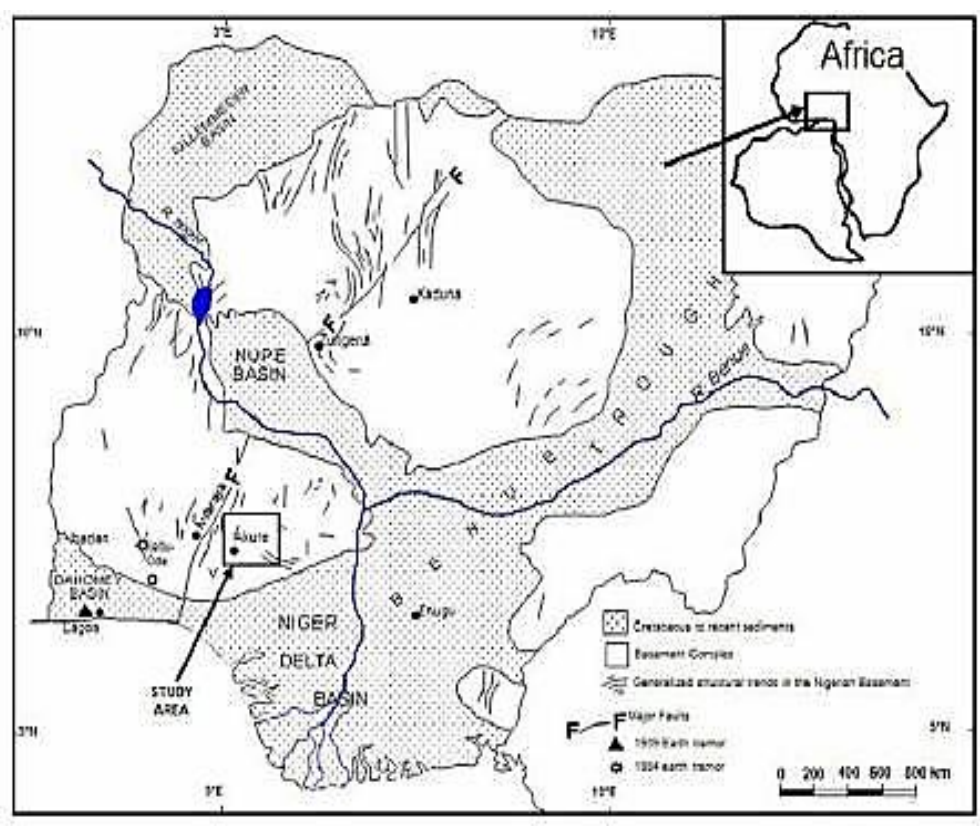

Figure 1: Simplified geological map of Nigeria indicating the study area (After [19])

\subsection{Planting Material}

Late maturing cultivar Maize (TZB-SR), obtained from the International Institute of Tropical Agriculture (IITA) Ibadan, Oyo State, was used for the experiment. Tithonia diversifolia an annual weed was gotten from road edges and farm boundaries.

\subsection{Experimental Design and Layout}

An area of land measuring $10 \mathrm{~m} \times 10 \mathrm{~m}$ was prepared. The prepared land was divided into nine (9) units; each unit has a size of $2 \mathrm{~m} \mathrm{X} 2 \mathrm{~m}$ and $1 \mathrm{~m}$ alleyway between blocks giving rise to twenty maize plant per unit with a spacing of 75 X $25 \mathrm{~cm}$. Ten plants were randomly tagged to monitor the progress of the plant. Manual weed control was employed at an interval of three weeks till harvest. The trial was a factorial experiment laid out in a Randomized Complete Block Design (RCBD) with three treatments. Treatments with sole mulch application were compared with each other. The treatments involved three levels of Tithonia diversifolia $[0 \mathrm{t} \mathrm{ha}$ 
Dayo-Olagbende et al., Int. Ann. Sci.; Vol. 8, Issue 1, pp: 114-119, 2020

${ }^{1}, 3 \mathrm{tha}^{-1}(1.2 \mathrm{~kg}$ per $4 \mathrm{~m}), 6 \mathrm{t} \mathrm{ha} \mathrm{-}^{-1}(2.4 \mathrm{~kg}$ per $\left.4 \mathrm{~m})\right]$ Mulching was done a week after planting.

\subsection{Data Collection}

Yield data (weight of wet grain, weight of dry grain, weight of cob, 1000-grain weight, root and shoot biomass (g) were recorded after maize was harvested 12 weeks after planting. Statistical Analysis System (SAS) was used to analyze the results obtained and means were separation using Duncan's Multiple Range Test (DMRT).

\subsection{Physico-chemical Characterization of Soil}

Prior to planting, top soil samples $(0-15 \mathrm{~cm})$ were randomly collected and bulked out of which composite sample was taken. The sample was allowed to dry and then passed through $2 \mathrm{~mm}$ sieve and afterwards analyzed for major chemical and physical properties. Soil $\mathrm{pH}$ was determined in distilled water using the $\mathrm{pH}$ meter in 1:2 soil solution, the organic carbon was determined by Walkley - Black wet oxidation method while soil organic matter content was calculated from organic carbon [20,21]. Particle size distribution was carried out using hydrometer method as described by [20] Exchangeable cations were extracted with neutral normal ammonium acetate solution. $\mathrm{Ca}$ and $\mathrm{Mg}$ were determined using Atomic Absorption Spectrophotometer while exchangeable $\mathrm{K}$ and sodium $(\mathrm{Na})$ were read with flame photometer [22-25]. Phosphorus (P) by Bray and Kurtz method and Percentage $\mathrm{N}$ was determined using the Kjeldahl method [26]. Bulk density was determined using core sampler method, soil moisture content by oven-dry method and infiltration rate was derived using the single ring method as described by [1]. Cation Exchange Capacity (CEC) was computed as the summation of exchangeable cations, Soil Porosity was derived using the following formula;

$$
\text { Soil porosity }=\left(1-\frac{\mathrm{db}}{\mathrm{dp}}\right) \times 100
$$

Where dp is particle density and db is bulk density

\section{Results}

Table 2 presents the pre- experiment chemical and physical properties of soils of the two sites used for the trial. The soil in Site 1 was a sandy clay loam with a sand content of $51.7 \mathrm{~g} / \mathrm{kg}$, silt content of $22.0 \mathrm{~g} / \mathrm{kg}$ and clay content of 26.3 $\mathrm{g} / \mathrm{kg}$. It was slightly acidic ( $\mathrm{pH}$ 6.23), and has moderate organic matter content $(2.57 \%)$. Total $\mathrm{N}(0.20 \%)$ is considered medium level for soils in southwestern Nigeria (FMANR, 1990). Available $\mathrm{P}$ was low with a value of $5.3 \mathrm{mg} / \mathrm{kg}$ while exchangeable $\mathrm{K}(0.19 \mathrm{cmol} / \mathrm{kg})$ was very low being below the standard $(0.20 \mathrm{cmol} / \mathrm{kg})$. The soil in Site 2 was sandy loam in texture with a sand content of $68.8 \mathrm{~g} / \mathrm{kg}$, silt content of 26.5 $\mathrm{g} / \mathrm{kg}$ and clay content of $5.7 \mathrm{~g} / \mathrm{kg}$. It is moderately acidic ( $\mathrm{pH}$ 6.02) and has a total $\mathrm{N}$ value of $0.14 \%$ which was moderately low. It has low organic matter content $(1.42 \%)$, low available $\mathrm{P}(3.8 \mathrm{mg} / \mathrm{kg})$ and very low exchangeable $\mathrm{K}$ at $0.11 \mathrm{cmol} / \mathrm{kg}$.

Table 2: Physico-chemical properties of the soils at the sites before experiment.

\begin{tabular}{lcc}
\hline Properties & Site 1 & Site 2 \\
\hline Soil pH $\left(\mathrm{H}_{2} \mathrm{O}\right)$ & 6.23 & 6.02 \\
Sand g/kg & 51.7 & 68.8 \\
Clay g/kg & 26.3 & 5.7 \\
Silt g/kg & 22.0 & 25.5 \\
Textural Class & Sandy Clay Loam & Sandy Loam \\
Moisture Content \% & 26.2 & 21.4 \\
Bulk Density $(\mathrm{g})$ & 1.36 & 1.25 \\
Total porosity \% & 46.9 & 51.2 \\
Infiltration $(\mathrm{cm} / \mathrm{hr})$ & 6.4 & 13.6 \\
Total N \% & 0.20 & 0.14 \\
Available P (mg/kg) & 5.3 & 3.8 \\
Organic carbon \% & 1.49 & 0.82 \\
Organic matter \% & 2.57 & 1.42 \\
K (cmol/kg) & 0.19 & 0.11 \\
Ca(cmol/kg) & 0.30 & 0.21 \\
Mg(cmol/kg) & 0.13 & 0.09 \\
Na(cmol/kg) & 0.25 & 0.14 \\
CEC(cmol/kg) & 5.44 & 4.27 \\
Base Saturation \% & 96.3 & 96.7 \\
Exchangeable Acidity & 1.42 & 0.98 \\
C/N Ratio & 7.00 & 6.20 \\
\hline
\end{tabular}

\subsection{Effects of Tithonia Mulch on Soil Physical Properties after Harvest of Maize}

Table 3 presents the effects of Tithonia mulch on soil physical properties at Sites 1 and 2. Moisture content as well as infiltration rate followed the same trend at both Sites 1 and 2. The treatment $\mathrm{M}_{2}$ had the highest moisture content as well as infiltration rate and $\mathrm{M}_{0}$ (the control) recorded the least. For both Sites 1 and 2, the bulk densities were inversely proportional to the porosities of the soil (the lower the bulk densities, the higher the porosities). It was also noticed that results 
Influence of Tithonia Diversifolia on Maize (Zea mays L.) Yield, Fertility and Infiltration Status of Two Clay Varied Soils

obtained at Site 1 were inverse to those obtained at Site 2. The highest bulk density was recorded in site 1 while at Site 2 , the highest was with $\mathrm{M}_{2}$.

Table 3: Effects of tithonia mulch (t/ha) on soil physical properties after harvesting of maize at both sites

\begin{tabular}{|c|c|c|c|c|c|}
\hline \multirow{2}{*}{ 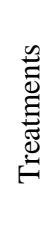 } & $\begin{array}{l}\stackrel{0}{\Xi} \\
\stackrel{0}{0} \\
\stackrel{0}{0} \\
\sum \\
\Sigma\end{array}$ & 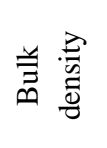 & 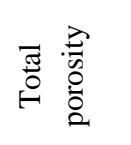 & $\begin{array}{l}\stackrel{\Xi}{\Xi} \\
\stackrel{\Xi}{\Xi} \\
\stackrel{\Xi}{\Xi} \\
\Xi\end{array}$ & \\
\hline & $(\%)$ & (g) & $(\%)$ & $(\mathrm{cm} / \mathrm{hr})$ & \\
\hline \multicolumn{6}{|c|}{ Site 1} \\
\hline $\mathrm{M}_{0}$ & $25.54 \mathrm{c}$ & $1.43 \mathrm{a}$ & $43.77 b$ & $9.74 \mathrm{c}$ & \\
\hline $\mathrm{M}_{1}$ & $36.31 \mathrm{~b}$ & $1.42 \mathrm{ab}$ & $49.63 \mathrm{ab}$ & $18.23 b$ & \\
\hline $\mathrm{M}_{2}$ & $42.92 \mathrm{a}$ & $1.39 b$ & $52.99 \mathrm{a}$ & $30.25 a$ & \\
\hline \multicolumn{6}{|c|}{ Site 2} \\
\hline $\mathrm{M}_{0}$ & $24.35 \mathrm{c}$ & $1.24 \mathrm{~b}$ & $51.48 \mathrm{a}$ & $13.84 \mathrm{c}$ & \\
\hline $\mathrm{M}_{1}$ & $28.12 b$ & $1.25 \mathrm{ab}$ & $51.04 \mathrm{ab}$ & $27.02 b$ & \\
\hline $\mathbf{M}_{2}$ & $29.99 a$ & $1.27 \mathrm{a}$ & $50.39 b$ & $31.35 \mathrm{a}$ & \\
\hline \multicolumn{6}{|c|}{$\begin{array}{l}\text { Means that follow the same letters are not significantly } \\
\text { 0.05) different according to Duncan's Multiple Range }\end{array}$} \\
\hline & $\begin{array}{l}\text { Eff } \\
\text { Cho } \\
\text { Ha }\end{array}$ & of $\mathrm{Ti}$ & $\begin{array}{l}\text { onia M } \\
\text { perties } \\
\text { ize }\end{array}$ & $\begin{array}{l}\text { h on } \\
\text { the En }\end{array}$ & \\
\hline
\end{tabular}

Tables 4 and 5 presents the effects of tithonia mulch on soil chemical properties at both sites 1 and 2 at harvest of maize. Organic $C$ contents at both Sites 1 and 2 were significantly ( $\mathrm{p}>0.05)$ different, the highest is $\mathrm{M}_{2}$ while the control was the lowest. Soil $\mathrm{pH}$ values were generally increased with tithonia mulch application to the soil at both Sites. The control had the lowest value for $\mathrm{pH}$ while the treatment $\mathrm{M}_{2}$ recorded the highest. From the results obtained from Site 1, there exist no difference between the control and $M_{1}$, while $M_{2}$ was higher than the remaining treatments (control and $\mathrm{M}_{1}$ ). Application of tithonia significantly increased the available $\mathrm{P}$ contents and total $\mathrm{N}$ of the soils over the control. The treatment $\mathrm{M}_{2}$ recorded the highest $\mathrm{P}$ and $\mathrm{N}$ contents while the control recorded the lowest contents at both Sites. At the two Sites, exchangeable $\mathrm{K}$ values followed the same trend as $\mathrm{N}$ and $\mathrm{P}$, with $\mathrm{M}_{2}$ having the highest. No significant $(p>0.05)$ difference existed between the control and $\mathrm{M}_{1}$. Exchangeable cations content $(\mathrm{Na}, \mathrm{Ca}$ and $\mathrm{Mg}$ ) at both Sites followed the same trend, with $\mathrm{M}_{2}$ recording the highest values while the control recorded the lowest. $\mathrm{M}_{0}$ (control) had the highest values for exchangeable acidity while $\mathrm{M}_{2}$ had the lowest. The CEC values at both Sites were highest with $\mathrm{M}_{2}$ while the least values were in the control. At Site 1, the control recorded the highest values for both $\mathrm{C} / \mathrm{N}$ ratio and base saturation while the least was in $\mathrm{M}_{2}$. At Site 2, no differences existed between both the base saturation and the $\mathrm{C} / \mathrm{N}$ ratio.

Table 4: Effects of tithonia mulch ( $\mathrm{kg} / \mathrm{ha}$ ) on soil chemical properties after harvest of maize at both sites

\begin{tabular}{|c|c|c|c|c|c|c|}
\hline Treatments & $\overline{\mathbf{N}}$ & $\overline{\mathbf{P}}$ & $\mathbf{K}$ & $\mathbf{C a}$ & $\mathbf{M g}$ & $\mathbf{N a}$ \\
\hline \multicolumn{7}{|c|}{$\begin{array}{l}\mathrm{mg} / \mathrm{ha} \\
\text { SITE } 1\end{array}$} \\
\hline $\mathbf{M}_{0}$ & $0.17 \mathrm{c}$ & $6.42 c$ & $0.19 b$ & $2.76 \mathrm{c}$ & $1.37 \mathrm{c}$ & $0.33 b$ \\
\hline $\mathbf{M}_{1}$ & $0.34 \mathrm{~b}$ & $19.85 b$ & $0.20 \mathrm{~b}$ & $3.97 \mathrm{~b}$ & $1.97 \mathrm{~b}$ & $0.33 b$ \\
\hline $\mathbf{M}_{2}$ & $0.45 \mathrm{a}$ & $29.00 \mathrm{a}$ & $0.25 \mathrm{a}$ & $4.38 \mathrm{a}$ & $2.20 \mathrm{a}$ & $0.34 \mathrm{a}$ \\
\hline \multicolumn{7}{|c|}{ SITE 2} \\
\hline $\mathbf{M}_{0}$ & $0.15 \mathrm{c}$ & $6.23 c$ & $0.12 b$ & $2.38 \mathrm{c}$ & $1.19 \mathrm{c}$ & $0.25 \mathrm{c}$ \\
\hline $\mathbf{M}_{1}$ & $0.31 \mathrm{~b}$ & $18.58 \mathrm{~b}$ & $0.14 \mathrm{~b}$ & $3.79 b$ & $1.89 \mathrm{~b}$ & $0.27 b$ \\
\hline $\mathbf{M}_{2}$ & $0.39 \mathrm{a}$ & $26.49 \mathrm{a}$ & $0.21 \mathrm{a}$ & $4.34 \mathrm{a}$ & $2.17 \mathrm{a}$ & $0.29 \mathrm{a}$ \\
\hline
\end{tabular}

Means that follow the same letters are not significantly ( $p>$ $0.05)$ different according to Duncan's Multiple Range Test.

Where, $\mathrm{M}_{0}=$ control, $\mathrm{M}_{1}=3 \mathrm{tha}^{-1}, \mathrm{M}_{2}=6 \mathrm{tha}^{-1}$

Table 5: Effects of tithonia mulch $(\mathrm{kg} / \mathrm{ha})$ on soil chemical properties after harvest of maize at both sites

\begin{tabular}{|c|c|c|c|c|c|c|}
\hline Treatments & pH & OC & EA & CEC & $\mathbf{B S}$ & $\mathbf{C} / \mathbf{N}$ \\
\hline & & $(\%)$ & & & $(\%)$ & \\
\hline \multicolumn{7}{|c|}{ SITE 1} \\
\hline $\mathbf{M}_{0}$ & $6.45 b$ & $1.04 \mathrm{c}$ & $2.18 \mathrm{a}$ & $4.71 \mathrm{c}$ & $96.61 \mathrm{a}$ & $6.18 \mathrm{a}$ \\
\hline $\mathbf{M}_{1}$ & $6.45 b$ & $1.73 b$ & $1.66 \mathrm{~b}$ & $6.73 b$ & $96.17 \mathrm{a}$ & $5.32 \mathrm{~b}$ \\
\hline $\mathbf{M}_{2}$ & $6.61 \mathrm{a}$ & $2.20 \mathrm{a}$ & $1.17 \mathrm{c}$ & $7.51 \mathrm{a}$ & $96.27 \mathrm{a}$ & $4.95 \mathrm{~b}$ \\
\hline \multicolumn{7}{|c|}{ SITE 2} \\
\hline Mo & $5.62 \mathrm{c}$ & $0.92 \mathrm{c}$ & $1.69 \mathrm{a}$ & $4.10 \mathrm{c}$ & $96.27 \mathrm{a}$ & $6.07 \mathrm{a}$ \\
\hline $\mathbf{M}_{1}$ & $5.80 \mathrm{~b}$ & $1.60 \mathrm{~b}$ & $1.49 \mathrm{~b}$ & $6.33 b$ & $96.08 \mathrm{a}$ & $5.26 \mathrm{a}$ \\
\hline $\mathbf{M}_{2}$ & $5.94 \mathrm{a}$ & $1.98 \mathrm{a}$ & $1.04 \mathrm{c}$ & $7.27 \mathrm{a}$ & $96.04 \mathrm{a}$ & $5.23 \mathrm{a}$ \\
\hline
\end{tabular}

Means that follow the same letters are not significantly (p> 0.05 ) different according to Duncan's Multiple Range Test.

Where, $\mathrm{M}_{0}=$ control, $\mathrm{M}_{1}=3 \mathrm{t} \mathrm{ha}^{-1}, \mathrm{M}_{2}=6 \mathrm{t} \mathrm{ha}^{-1}$ 
Dayo-Olagbende et al., Int. Ann. Sci.; Vol. 8, Issue 1, pp: 114-119, 2020

\subsection{Effect of Tithonia Mulch on Maize Grain Yield and Plant Biomass}

Tables 6 shows the effects of tithonia mulch on maize plant biomass and yield at harvest at Site 1 and 2. The control gave the lowest wet shoot biomass at both Sites and $\mathrm{M}_{2}$ gave the highest. In site 1 , the dry shoot biomass had $\mathrm{M}_{2}$ as having the highest dry shoot and the control the least. At site $2, \mathrm{M}_{2}$ had the highest, but no significant ( $\mathrm{p}>$ 0.05) difference existed between $\mathrm{M}_{1}$ and the control. Treatment $\mathrm{M}_{2}$ gave the highest value for both dry and wet root biomass and the control gave the least at both sites. At Site 1, treatment $\mathrm{M}_{2}$ had the highest weight of both wet and dry grains while the control had the least.

Table 6: Effects of tithonia mulch ( $\mathrm{kg} / \mathrm{ha}$ ) on maize (Zea mays L.) yield and plant biomass at both sites

\begin{tabular}{|c|c|c|c|c|c|c|}
\hline 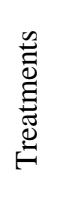 & 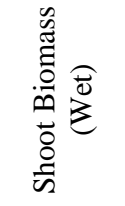 & 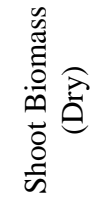 & 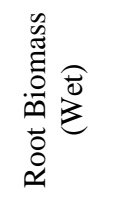 & 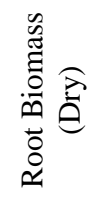 & 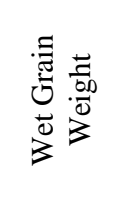 & $\begin{array}{l}\Xi \vec{\Xi} \\
\overrightarrow{0} \\
\vec{b} \\
\overrightarrow{0}\end{array}$ \\
\hline & \multicolumn{6}{|c|}{$\begin{array}{r}\text { SITE } 1 \\
\text { SIT }\end{array}$} \\
\hline M0 & $122.17 \mathrm{c}$ & $32.01 \mathrm{c}$ & $35.12 \mathrm{c}$ & $18.07 \mathrm{c}$ & $149.77 b$ & $63.98 \mathrm{a}$ \\
\hline M1 & $144.42 b$ & $35.88 \mathrm{~b}$ & $41.61 b$ & $29.20 b$ & $182.24 \mathrm{a}$ & $75.69 a$ \\
\hline M2 & $172.83 \mathrm{a}$ & $49.87 \mathrm{a}$ & $\begin{array}{l}\text { 49.10a } \\
\text { SITE } 2\end{array}$ & $39.47 \mathrm{a}$ & $188.22 \mathrm{a}$ & $77.62 \mathrm{a}$ \\
\hline M0 & $119.32 \mathrm{c}$ & $33.58 b$ & $34.19 \mathrm{c}$ & $15.24 \mathrm{c}$ & $127.92 \mathrm{c}$ & $50.67 \mathrm{c}$ \\
\hline M1 & $141.37 \mathrm{~b}$ & $34.43 b$ & $41.18 b$ & $25.44 b$ & $152.26 b$ & $59.87 b$ \\
\hline M2 & $160.47 \mathrm{a}$ & 51.61 & $44.92 \mathrm{a}$ & $31.04 \mathrm{a}$ & $167.33 \mathrm{a}$ & $68.09 \mathrm{a}$ \\
\hline
\end{tabular}

\subsection{Effect of Tithonia Mulch on Weight of Maize Cob}

Fig 2 presents the effect of tithonia on weight of maize cob at both sites. Similar trend was obtained at both sites with treatment $\mathrm{M}_{2}$ having the highest and the control the lowest. Although Site 1 had the highest weight of cob compared to site 2 , possibly because of variation in soil texture which was expected because nutrients are not easily leached from soils with higher clay content. Fig 3 compares results on both sites, despite the same trend; Site 1 had the highest result. Again, this is most possibly because of variation in soil texture.

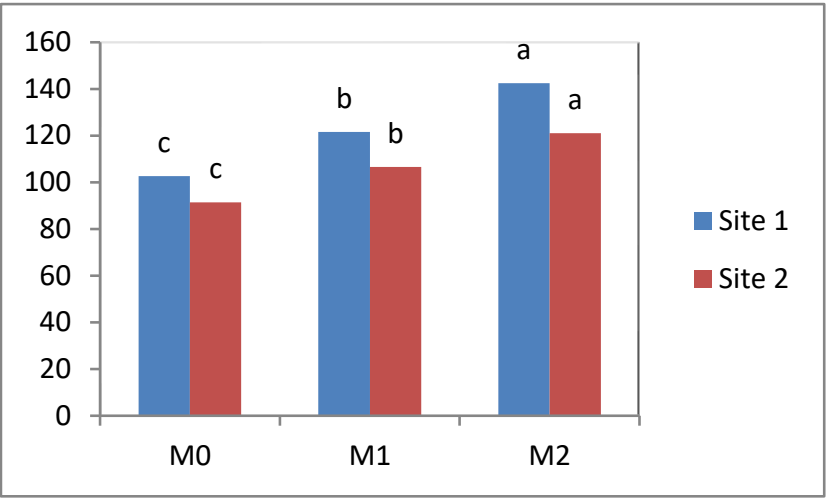

Figure 2: Effect of Levels Tithonia Mulch on Maize Cob weight on Site 1 and 2

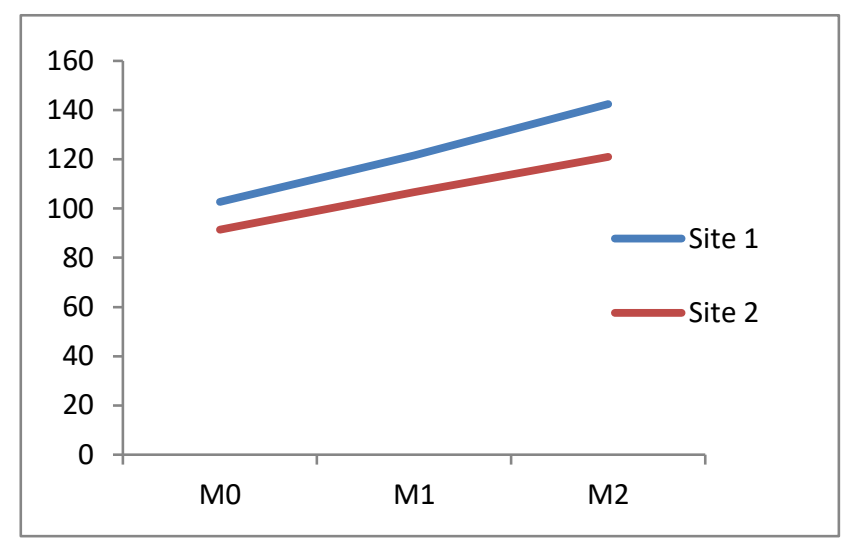

Figure 3: Effect of Levels of Tithonia Mulch on Maize Grain Yield on Site 1 and 2

\section{Conclusions}

Application of the mulch at $6 \mathrm{t} \mathrm{ha}^{-1}$ gave the highest maize grain yield (Fig 3; Table 6) for sandy clay loam soils (Site 1) and Sandy loam (site 2 ), although site 1 had higher yield when compared to site 2 , this was possibly because of the inherent properties and nutrient status of the soil. Application of mulch (organic matter) to the soil will attract microbes, insects and worms, thereby creating more continuity pores which would in turn improve soil infiltration rate and it is evident through increase in soil porosity and improvement in infiltration rate. When compared with the control on both sites, the treatments with mulch applications had better fertility status after harvesting of maize. Using this readily available weed (Tithonia diversifolia) as mulch for soil sustainability, crop growth and yield is hereby advised. Although this research concluded on 6 $\mathrm{t} / \mathrm{ha}$, further research should look into increasing the quantity applied. 


\section{Competing Interests}

The authors declared that there are no potential conflict of interest concerning this work.

\section{How to Cite this Article:}

O. Dayo-Olagbende, O. Akingbola, G. Afolabi, and B. Ewulo, "Influence of Tithonia Diversifolia on Maize (Zea mays L.) Yield, Fertility and Infiltration Status of Two Clay Varied Soils", Int. Ann. Sci., vol. 8, no. 1, pp. 114119, Nov. 2019. doi: 10.21467/ias.8.1.114-119

\section{References}

[1] O. O. Akingbola, A.J. Adeyemo, S.O. Oladele and S.O. Ojeniyi. "Physical Status and Infiltration Dynamics of Tropical Alfisol of South- Western Nigeria as Affected by Poultry Manure," Appl Trop Agri. vol 21 issues 2, pp. 102$111,2016$.

[2] M. B. Sharu, M. Yakubu, S. S. Noma, and A. I. Tsafe. "Characterization and Classification of Soils on an Agricultural landscape in Dingyadi District, Sokoto State, Nigeria,” Nig J B Appl Sci. vol 21 issues 2 pp. 137-147. June 2013

[3] A.J. Adeyemo, O.O. Akingbola, and S.O. Ojeniyi. "Effects of poultry manure on soil infiltration, organic matter contents and maize performance on two contrasting degraded alfisols in southwestern Nigeria." Int J Recycl Org W Agri, pp.1-8. 27 May 2019.

[4] G. Zenawi and A. Mizan. "Effect of Nitrogen Fertilization on the Growth and Seed Yield of Sesame (Sesamum indicum L.)," Int J Agro, Volume 2019, Article ID 5027254, pp.7, 2019.

[5] J.M. Alston and P.G. Pardey. "Agriculture in the Global Economy." J Econ Persp. vol 28 issue 1, pp. 121-146. 2014.

[6] T.O. Amodu, G.O. Dayo- Olagbende and O.O. Akingbola. "Effect of Selected Organic Residues and Inorganic Fertilizers on the Performance of Okra (Abelmoschus esculentus)." Sust Food Prod. vol 5, pp.17-23. 11 January 2019.

[7] FAO, IFAD, WFP. "The State of Food Insecurity in the World 2012: Economic growth is necessary but not sufficient to accelerate reduction of hunger and malnutrition.” Rome, FAO. 2012.

[8] T.L. Roberts. "The role of fertilizer in growing the world's food. Top Crop Manager." 2010.

[9] S.L. McGeehan. "Impact of Waste Materials and Organic Amendments on Soil Properties and Vegetative Performance." Appl Env Soil Sci. Article ID 907831.pp 11. 2012.

[10] Y. Chen, M. Camps-Arbestain, Q. Shen, B. Singh, M. Luz Cayuela, "The long-term role of organic amendments in building soil nutrient fertility: a meta-analysis and review." Nutr Cycl Agroecosyst, vol 111, pp.103-125. 4 January 2018.

[11] S.M. Eldridge, K.Y. Chan, N.J. Donovan, F. Saleh, L. Orr, I. Barchia. "Agronomic and economic benefits of greenwaste compost for peri-urban vegetable production implications for food security." Nutr Cycl Agroecosyst, vol 111, pp.155-173. 25 June, 2018.

[12] L.X. León Castro, and J. K. Whalen. "Nitrogen Supply from Green Manure Enhanced with Increased Tillage Frequency: A Note." Agron. J., vol 111, pp. 935-941. 2019.

[13] O. O. Akingbola and G.O. Dayo-Olagbende. "Green manuring to a better soil physical condition." Agri. Res. Tech:: Open Access J. vol 11 issues 3, Article ID 5558132017. 31 August, 2017.

[14] T.T. Nguyen, S. Fuentes and P.Marschner. "Effect of incorporated or mulched compost on leaf nutrient concentrations and performance of Vitis vinifera cv. Merlot." J. Soil Sci. Plant Nutr, vol 13 issues 2. 2013.

[15] P. C. Eze, A. J. Odofin, I.N. Onyekwere, J. J. Musa, and P.
A. Tsado. "Influence of Rice Husk - Mulch on Soil Water Balance Components under Sorghum and Millet Crops in Maiduguri, Semi Arid Northeast Nigeria." J Exp Agri Intl, vol 33 issues 4, pp.1-7. 2019.

[16] R. Chemutai, J. Mwine, R. Awichi, and G. Bwogi. "Effects of NPK and plant tea manure (Tithonia diversifolia) on growth rate of amaranth (Amaranthus cruentus L.) in soilless growing media.” Afri J Agri Res, vol 14 issues 27, pp. 1169-1179, 2019

[17] Jama, B., Palm, C.A., Buresh, R.J. et al. Agroforestry Systems (2000) 49: 201

[18] A. M. Mazen D.E.M. Radwan and A.F. Ahmed. "Growth Responses of Maize Plants Cultivated in Sandy Soil Amended by Different Superabsorbant Hydrogels," J. Plant Nutri., vol 38 issues 3, pp 325-337. 2015.

[19] F.Y.B. Anifowose and F. Kolawole. 'Tectono-Hydrological Study of Akure Metropolis, Southwestern Nigeria.Hydrology for Disaster Management." Spec Pub Nig Ass Hydro Sci. pp. 106-120, 2012.

[20] T.M. Agbede, A.O Adekiya and J.S Ogeh. "Response of soil properties and yam yield to Chromolaena odorata (Asteraceae) and Tithonia diversifolia (Asteraceae) mulches." Arch Agro Soil Sci, vol. 60 issues 2, pp. 209-224, 2014.

[21] D. W. Nelson, and L. E. Sommers "Total carbon, organic carbon and organic matter. In: Page, A. L, R.H. Miller and D.R.Keeney (eds). Methods of Soil Analysis, part 2." Ame Soc Agro, Madison, Wisconsin, USA. pp 539-579.

[22] Y. Zhang, M. Xiao, Y. Dong and Y. Jiang. Determination of Soil Exchangeable Base Cations by Using Atomic Absorption Spectrophotometer and Extraction with Ammonium Acetate. Guang pu xue yu guang pu fen xi = Guang pu, vol 32 pp 2242-2245. 2012.

[23] J. Bremner. "Determination of nitrogen in soil by the Kjeldahl method." J Agri Sci, vol 55 issues 1 pp. 11-33. 1960.

[24] B. Vaughan, J. Denning and H. Frank. "Bray and Kurtz phosphorus ( $\mathrm{p} 1), 1 \mathrm{~m}$ potassium chloride, and saturated calcium oxide extraction of soil nitrate comparison to $2 \mathrm{~m}$ potassium chloride, Comm in Soil Sci and Plant Ana, vol 26 issues 3-4, pp. 453-457. 1995.

[25] G.O. Dayo- Olagbende , O.O. Akingbola, B.S. Ewulo "Combined Effects of Tithonia Mulch and Urea Fertilizer on Soil Physico-Chemical Properties and Maize Performance," Journal of Sustainable Agriculture, Volume 10 issue 1, pp 86-93. 2019.

[26] E. Solomon. "Combined Application of Phosphorus Fertilizer with Tithonia Biomass Improves Grain Yield and Agronomic Phosphorus Use Efficiency of Hybrid Maize, ”Int J Agro, vol. 2019, Article ID 6167384, 9 pages.

\section{Publish your research article in AIJR journals- $\checkmark \quad$ Online Submission and Tracking $\checkmark \quad$ Peer-Reviewed $\checkmark \quad$ Rapid decision $\checkmark \quad$ Immediate Publication after acceptance $\checkmark \quad$ Articles freely available online $\checkmark \quad$ Retain full copyright of your article. Submit your article at journals.aijr.in}

Publish your books with AIJR publisher$\checkmark \quad$ Publish with ISBN and DOI. $\checkmark \quad$ Publish Thesis/Dissertation as Monograph. $\checkmark \quad$ Publish Book Monograph. $\checkmark \quad$ Publish Edited Volume/ Book. $\checkmark \quad$ Publish Conference Proceedings $\checkmark \quad$ Retain full copyright of your books.

Submit your manuscript at books.aijr.org 